\title{
Functional Role of C-Terminal Cytoplasmic Tail of Rat Vanilloid Receptor 1
}

\author{
Viktorie Vlachová, ${ }^{1}$ Jan Teisinger, ${ }^{1}$ Klára Sušánková, ${ }^{1}$ Alla Lyfenko, ${ }^{1}$ Rüdiger Ettrich, ${ }^{2,3}$ and Ladislav Vyklický ${ }^{1}$ \\ ${ }^{1}$ Institute of Physiology, Academy of Sciences, 14220 Prague 4, Czech Republic, ${ }^{2}$ Institute of Physical Biology, University of South Bohemia, 37333 Nové \\ Hrady, Czech Republic, and ${ }^{3}$ Department of Biochemistry, Faculty of Science, Charles University, 12840 Prague 2, Czech Republic
}

The vanilloid receptor [transient receptor potential (TRP)V1, also known as VR1] is a member of the TRP channel family. These receptors share a significant sequence homology, a similar predicted structure with six transmembrane-spanning domains (S1-S6), a poreforming region between S5 and S6, and the cytoplasmically oriented C- and N-terminal regions. Although structural/functional studies have identified some of the key amino acids influencing the gating of the TRPV1 ion channel, the possible contributions of terminal regions to vanilloid receptor function remain elusive. In the present study, C-terminal truncations of rat TRPV1 have been constructed to characterize the contribution of the cytoplasmic C-terminal region to TRPV1 function and to delineate the minimum amount of $\mathrm{C}$ tail necessary to form a functional channel. The truncation of 31 residues was sufficient to induce changes in functional properties of TRPV1 channel. More pronounced effects of $\mathrm{C}$-terminal truncation were seen in mutants lacking the final 72 aa. These changes were characterized by a decline of capsaicin-, $\mathrm{pH}$-, and heat-sensitivity; progressive reduction of the activation thermal threshold (from 41.5 to $28.6^{\circ} \mathrm{C}$ ); and slowing of the activation rate of heat-evoked membrane currents $\left(Q_{10}\right.$ from 25.6 to 4.7$)$. The voltage-induced currents of the truncated mutants exhibited a slower onset, markedly reduced outward rectification, and significantly smaller peak tail current amplitudes. Truncation of the entire TRPV1 C-terminal domain (155 residues) resulted in a nonfunctional channel. These results indicate that the cytoplasmic $\mathrm{COOH}$-terminal domain strongly influences the TRPV1 channel activity, and that the distal half of this structural domain confers specific thermal sensitivity.

Key words: capsaicin receptor; TRPV1; C-terminal domain; heat transduction; heat sensitivity; voltage-gated cation channel

\section{Introduction}

Vanilloid receptor 1 [transient receptor potential (TRP)V1, formerly VR1] has been suggested to function as a multimodal signal transducer of noxious stimuli in the mammalian somatosensory system (Caterina et al., 1997). Noxious thermal stimuli $\left(>43^{\circ} \mathrm{C}\right)$, acidic $\mathrm{pH}(<6.8)$, or the alkaloid irritant capsaicin are required to open the TRPV1 channel. At room temperature and a $\mathrm{pH}$ of 7.3, TRPV1 behaves as a voltage-gated outwardly rectifying nonselective cation channel, because it can be activated strongly by depolarizing voltage steps in the absence of any agonist (Chuang et al., 2001; Reeve and Bevan, 2002; Vlachová et al., 2002). Although much knowledge of the structure and function of the TRPV channel subfamily has accumulated recently (for review, see Clapham et al., 2001; Gunthorpe et al., 2002), the critical structural domains and the mechanisms by which various external stimuli translate into channel gating remain poorly understood.

The finding that disruption of the TRPV1 gene has minimal effects on thermal nociception (Caterina et al., 2000; Davis et al., 2000) and the identification of TRPV2 as a heat receptor with a high temperature threshold (Caterina et al., 1999) suggest that other receptors homologous to TRPV1 may be implicated in

\footnotetext{
Received July 23, 2002; revised Nov. 25, 2002; accepted Dec. 4, 2002.

This work was supported by Grants 305/00/1639 and 305/03/0802 from the Grant Agency of the Czech Republic, by Research Project 5011922 of the Academy of Sciences of the Czech Republic, and by Grants LN00B122, MSM 113100001, MSM 12310001, and MSM 113100003 of the Ministry of Education, Youth, and Sports of the Czech Republic. We thank Charles Edwards for a critical reading of this manuscript.

Correspondence should be addressed to Dr. Vlachová Viktorie, Institute of Physiology, Academy of Sciences of the Czech Republic, Vídenská 1083, 14220 Prague 4, Czech Republic. E-mail: vlachova@biomed.cas.cz.

Copyright $\odot 2003$ Society for Neuroscience $\quad 0270-6474 / 03 / 231340-11 \$ 15.00 / 0$
}

thermosensation. Indeed, TRPV3 (Smith et al., 2002; Xu et al., 2002) $\left(\sim 39^{\circ} \mathrm{C}\right)$ and TRPV4 (Liedtke et al., 2000; Guler et al., 2002) have been found to show thermal sensitivity. A TRPV1 variant, the stretch-inactivated channel (SIC), has a truncated $\mathrm{N}$-terminal domain and shares identical transmembranespanning domains with TRPV1 (Schumacher et al., 2000a). The C-terminal domain of SIC is identical to the corresponding C-terminal domain of TRPV4 except for aspartate 494. This channel can be activated by hypertonic solutions; however, it is insensitive to capsaicin. Another TRPV1 variant, the VR 5' splice variant, which is also insensitive to vanilloids, low $\mathrm{pH}$, and thermal stimuli, encodes a C-terminal domain identical to TRPV1 but lacks the major part of the $\mathrm{N}$ terminal (Schumacher et al., $2000 \mathrm{~b}$ ). The above results suggest that the $\mathrm{N}$-terminal domain of TRPV1 is essential for the formation of functional ion channels, rather than specifically lacking an important functional region. It has been suggested that the C-terminal domains of the TRP receptors act to ensure the uniqueness of their function (Xue et al., 2001).

In the predicted TRPV1 C terminal, a serine residue $\mathrm{S} 800$ that can be directly phosphorylated by protein kinase C (Numazaki et al., 2002) and a putative Walker-type nucleotide-binding site (L726-W740) have been identified to date (Kwak et al., 2000). However, how the C-terminal domain contributes to the conformational stability of TRPV 1 channel and the extent to which it influences its function still remain to be determined. In this study, we demonstrate that the cytosolic C-terminal region of the TRPV1 channel contains a domain or domains responsible for a steep temperature dependence of the TRPV1 heat-evoked re- 
sponses. We hypothesize that this region is also important for the regulation of the capsaicin-, low $\mathrm{pH}$-, and voltage-induced channel activity.

\section{Materials and Methods}

Cell culture and expression of cDNA. Human embryonic kidney (HEK) 293T cells (SD 3515; American Type Culture Collection, Manassas, VA) were cultured in Opti-MEM I (Invitrogen, Gaithersburg, MD) supplemented with $5 \%$ fetal bovine serum. Cells were plated onto dishes coated with poly-L-lysine at a density of $\sim 180,000 \mathrm{cells} / \mathrm{cm}^{2}$. HEK293T cells were transiently transfected with 300-500 ng per dish of recombinant plasmid DNA encoding wild-type (WT) or mutant rat TRPV1 in pcDNA3 vector (wild type provided by D. Julius, University of California, San Francisco, CA) using the Lipofectamine 2000 method according to the manufacturer's protocol (Invitrogen, Paisley, UK). To identify the transfected cells in the electrophysiological experiments, DNA plasmid encoding green fluorescent protein (GFP) in pQBI 25 vector (TaKaRa, Tokyo, Japan) was cotransfected at a concentration of $500 \mathrm{ng}$ per dish. Transfected cells were replated onto glass coverslips (three $12 \mathrm{~mm}$ coverslips per $35 \mathrm{~mm}$ dish) coated with poly-L-lysine. Electrophysiological and immunohistochemical examination was performed $24-48 \mathrm{hr}$ after transfection. For each experimental group, five to eight GFP-positive cells per coverslip were studied from at least four different (independent) transfections.

Construction of C-terminal deletions of TRPV1. Rat TRPV1 C-terminal deletions were constructed by PCR amplification using rat TRPV1specific primers synthesized to contain a point mutation converting the respective nucleotides at positions Q808, R797, E767, E761, K735, and E684 to a stop codon (Fig. 1). The QuikChange XL site-directed mutagenesis kit (Stratagene, La Jolla, CA) was used according to the manufacturer's protocol to perform point mutations in TRPV1. The overlapping primer pairs were as follows: TRPV1-C $\Delta 31,5^{\prime}$-GA GAT AGA CAT GCC ACC TAG CAG GAA GAA GTT CAA CTG-3' (sense) and 5' -CAG TTG AAC TTC TTC CTG CTA GGT GGC ATG TCT ATC TC-3' (antisense); TRPV1-C $\Delta 42$, (double mutation), 5' -CC CTG GTT CCC CTT CTG TGA GAT GCA AGC ACT CGA GAT AG-3' (sense) and 5'-CT ATC TCG AGT GCT TGC ATC TCA GAG AAG GGG AAC CAG GG-3' (antisense); TRPV1-C $\Delta 72,5^{\prime}$-G GAC CCA GGC AAC TGT TAG GGC GTC AAG CGC ACC CTG AGC-3' (sense) and 5' -GCT CAG GGT GCG CTT GAC GCC CTA ACA GTT GCC TGG GTC C-3' (antisense); TRPV1-C $\Delta 78,5^{\prime}$-GTG GGT ATC ATC AAC TAG GAC CCA GGC AAC TGT GAG GGC G-3' (sense) and 5' -C GCC CTC ACA GTT GCC TGG GTC CTA GTT GAT GAT ACC CAC-3' (antisense); TRPV1-C $\Delta 104$, $5^{\prime}$-G GTG GGG TTC ACT CCT GAC GGC TAG GAT GAC TAC CGG TGG-3' (sense) and 5' -CCA CCG GTA GTC ATC CTA GCC GTC AGG AGT GAA CCC CAC C-3' (antisense); TRPV1-C $\Delta 155$, 5' -CTC ATT GCT CTC ATG GGT TAG ACC GTC AAC AAG ATT GC-3' (sense) and 5'-GC AAT CTT GTT GAC GGT CTA ACC CAT GAG AGC AAT GAG-3' (antisense). Base changes introducing the stop codon are in bold type; italic type indicates the inserted point mutation. All site-directed mutated constructs were confirmed by DNA sequencing using an automated sequencer (ABI PRISM 3100; Applied Biosystems, Foster City, CA).

Immunohistochemistry. Polyclonal anti-VR1 raised against the peptide corresponding to the $\mathrm{N}$ terminal of rat VR1 (Affinity BioReagents, Golden, CO) was diluted 1:1000 in PBS. FITC-conjugated donkey antirabbit IgG (Abcam, Cambridge, UK) was used in a 1:100 dilution in PBS as the secondary antibody. Before seeding and transfection of the cells, three coverslips were placed in the culture dish. Twenty-four hours after transfection, the cells on the coverslips were washed once with PBS, fixed with $4 \%$ paraformaldehyde for $30 \mathrm{~min}$, and permeabilized with $0.5 \%$ Triton X-100 in PBS for 5 min. After permeabilization, the cells were washed three times for $10 \mathrm{~min}$ in PBS and then incubated for $30 \mathrm{~min}$ in PBS solution with $0.25 \%$ BSA and $0.25 \%$ gelatin to eliminate nonspecific binding. Cells were incubated overnight at $4^{\circ} \mathrm{C}$ with primary antibody, washed three times in PBS, incubated with secondary antibody for $1 \mathrm{hr}$, and washed again three times in PBS. Immunostained HEK293T cells were visualized using confocal laser scanning microscopy (MRC 600;
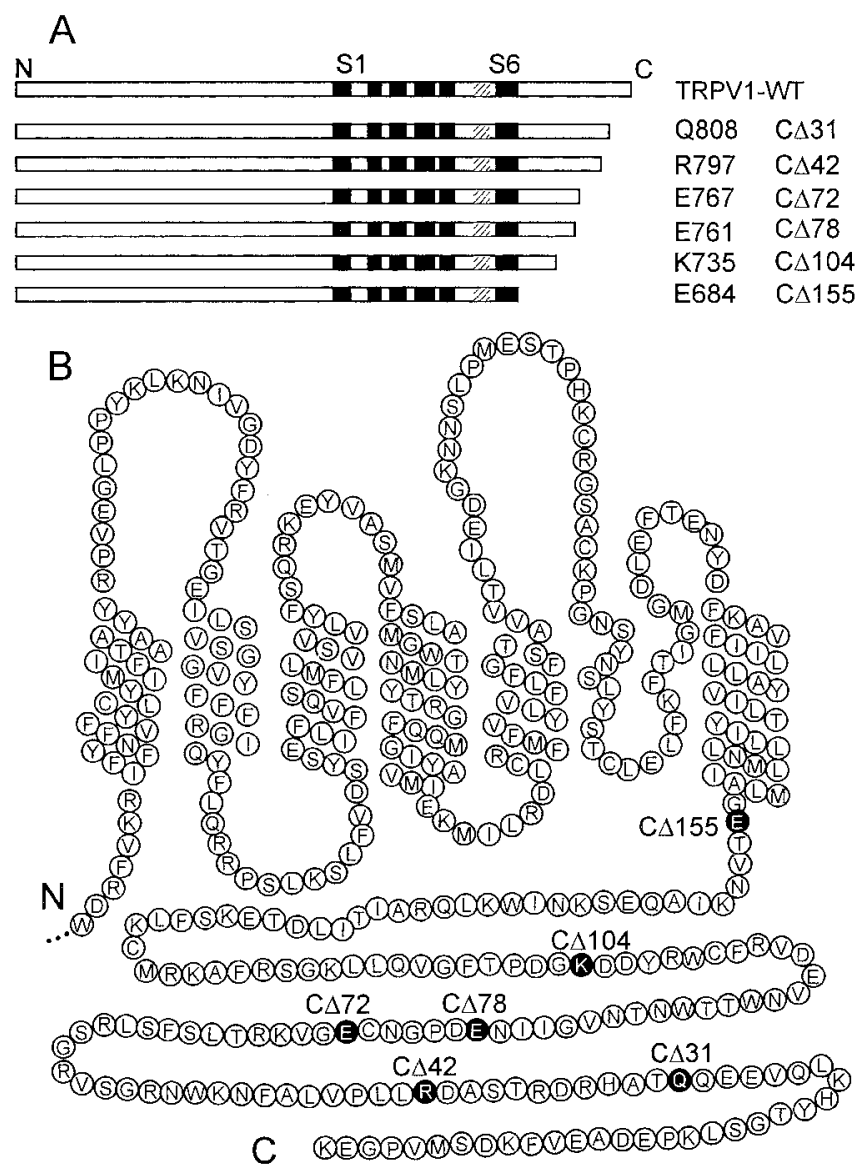

Figure 1. C-terminal truncations of vanilloid receptor TRPV1. $A$, Schematic representation of TRPV1 C-terminal deletions showing the six transmembrane-spanning domains, S1-S6, and a pore-forming region (hatched bars). $B$, Putative membrane topology and amino acids (in circles) of the C-terminal half of the rat TRPV1 receptor with indicated locations of the amino acids at which the stop codon has been introduced. $C \Delta 31, C \Delta 42, C \Delta 72, C \Delta 78, C \Delta 104$, and $C \Delta 155$ correspond to the mutated Q808, R797, E767, E761, K735, and E684, respectively.

Bio-Rad, Hercules, CA) attached to an inverted microscope (Nikon Diaphot; Nikon, Tokyo, Japan).

Electrophysiology. Whole-cell membrane currents were recorded using an Axopatch-1D amplifier and pClamp8 software (Axon Instruments, Foster City, CA). Electrodes were pulled from borosilicate glass; after fire polishing and filling, they had a resistance of $2-4 \mathrm{M} \Omega$. The series resistance was usually $<10 \mathrm{M} \Omega$ and was compensated to $\sim 80 \%$. A system for fast superfusion of the neurons was used for drug and heat application. It consisted of a manifold of seven fused silica capillaries connected to a common outlet made from a glass capillary around which insulated copper wire (20 $\mu \mathrm{m}$ thick) was coiled to pass direct current for heating the solutions superfusing the neuron under investigation (Dittert et al., 1998). The temperature of the superfusing solution was measured by a miniature thermocouple inserted into the outlet capillary near its orifice that was placed $<100 \mu \mathrm{m}$ from the cell under investigation. Before and after the test solutions, the cells were superfused with control extracellular solution of the following composition (in mM): 160 $\mathrm{NaCl}, 2.5 \mathrm{KCl}, 1 \mathrm{CaCl}_{2}, 2 \mathrm{MgCl}_{2}, 10 \mathrm{HEPES}$, and 10 glucose, $\mathrm{pH}$ adjusted to 7.3 with $\mathrm{NaOH}$. The intracellular pipette solution contained (in mM): 125 Cs-gluconate, $15 \mathrm{CsCl}, 5$ EGTA, 10 HEPES, $2 \mathrm{NaCl}$, and $0.5 \mathrm{CaCl}_{2}, \mathrm{pH}$ adjusted to 7.3 with $\mathrm{CsOH}$. Capsaicin was dissolved in $100 \mu \mathrm{l}$ of DMSO and diluted with $0.9 \mathrm{ml}$ of distilled water to make a stock solution of $1 \mathrm{~mm}$.

Molecular modeling of the TRPV1 C-terminal structure. The C-terminal sequence from 690 to 838 was aligned with the known x-ray structure of the fragile histidine triad (FHIT) protein, extracted from the Protein Data Bank (entry 1FIT; http://www.rcsb.org/pdb/). The primary structure of this protein shows a high degree of similarity (44\%) with the TRPV1 C terminal. The primary structures were aligned with the tem- 
plate structures by ClustalX (Thompson et al., 1997) and adjusted manually when necessary. The alignment used for additional modeling is shown in Figure 9A. Three-dimensional models of the $\mathrm{C}$ tail constituted by all nonhydrogen atoms were generated by the Modeller 6 package (Sali and Blundell, 1993). All the obtained models were subjected to a short simulated annealing refinement protocol available in Modeller. The representative model was that with the lowest Modeller target function value. For additional refinement, hydrogen atoms were added, and the generated structure was minimized to convergence of the energy gradient less a $0.01 \mathrm{kcal} / \mathrm{mol}$ using the Powell minimizer and the Tripos force field included in the Sybyl/Maximin2 module (Tripos, St. Louis, MO). Finally, the tertiary structure models were checked with Procheck (Laskowski et al., 1993).

Statistical analysis. Data are expressed as means \pm SEM. Overall statistical significance was determined by ANOVA, if not stated otherwise. In cases of significance $(p<0.05)$, statistical comparisons were performed by Student's $t$ test for individual groups. A rectification index (RI) of voltage-gated TRPV1-mediated whole-cell membrane currents was calculated using the following equation: $\mathrm{RI}=\left[I_{+60} /\left(60-V_{\text {rev }}\right)\right] /$ $\left[I_{-40} /\left(-40-V_{\text {rev }}\right)\right]$. Here, $I_{+60}$ and $I_{-40}$ are the steady-state amplitudes of the responses recorded at holding potentials of +60 and $-40 \mathrm{mV}$, and $V_{\text {rev }}$ is the estimated reversal potential.

The temperature coefficient $Q_{10}$ was used to characterize the temperature dependence of the membrane current (Vyklický et al., 1999). Data sampled at the rising phase of the temperature ramp were pooled every $0.5^{\circ} \mathrm{C}$. The absolute current values were plotted on a log scale against the reciprocal of the absolute temperature (Arrhenius plot). $Q_{10}$ values were determined by using the following formula: $Q_{10}=\exp \left[\Delta T \times E_{\mathrm{a}} /(R \times\right.$ $\left.T_{1} \times T_{2}\right)$ ], where $R$ is the gas constant, $\Delta T=10$ Kelvin, and $E_{\mathrm{a}}$ is an apparent activation energy estimated from the slope of the Arrhenius plot between absolute temperatures $T_{1}$ and $T_{2}$. The thermal thresholds for wild-type and TRPV1 mutant activation were measured from the temperatures at which the inward currents plotted on a logarithmic scale declined significantly from a straight line. For this purpose, piecewise linear regression was adapted using SigmaPlot 2000 (SPSS Inc., Chicago, IL). Dose-response data were fitted to the Hill equation, as follows: $I=$ $I_{\max }\left[(\text { capsaicin })^{n} /\left([\text { capsaicin }]^{n}+\mathrm{EC}_{50}{ }^{n}\right)\right]$, where $I$ is the normalized current at a given concentration of capsaicin, $I_{\max }$ is the maximal current, $\mathrm{EC}_{50}$ is the concentration of half-maximal activation, and $n$ is the Hill coefficient.

\section{Results}

\section{C-terminal truncations reduce the TRPV1 responsiveness to} capsaicin and low $\mathrm{pH}$

To delineate the functional role of the C-terminal domain in TRPV1 activation, the whole-cell membrane currents elicited by capsaicin, low $\mathrm{pH}$, and heat stimuli $\left(47^{\circ} \mathrm{C}\right)$ in HEK293T cells transfected with either wild-type rat TRPV1 receptor or the C-terminal truncated mutants were recorded. Interactions between chemical and thermal stimuli were measured by applying a $3 \mathrm{sec}$ temperature ramp from 24 to $47^{\circ} \mathrm{C}$ at the steady state of the capsaicin- or low $\mathrm{pH}$-induced responses (Fig. $2 \mathrm{~A}$ ). At room temperature and a holding potential of $-70 \mathrm{mV}$, capsaicin $(1 \mu \mathrm{M})$ induced significant inward membrane currents in all cells expressing wild type; however, the magnitudes of the responses showed a large variation: a median of $1.5 \mathrm{nA}$ (mean, $1.5 \pm 0.4 \mathrm{nA}$; $n=29)$ and a range between 20 and $7 \mathrm{nA}$. The proton-induced currents were measured in the steady state to remove the contribution of the fast inactivating human acid-sensing ion channels, which are constitutively expressed in HEK293 cells (Gunthorpe et al., 2001). As with capsaicin, the variations of the magnitudes of the responses induced by extracellular exposure to $\mathrm{pH} 5$ were large (from 0.4 to $7 \mathrm{nA} ; 2.3 \pm 0.4 \mathrm{nA} n=15$ ).

Deletions of 31 and 42 residues from the $\mathrm{C}$ terminal $(\mathrm{C} \Delta 31$ and $\mathrm{C} \Delta 42$ ) did not cause significant changes in capsaicin- and protoninduced maximum currents at room temperature (Fig. $2 \mathrm{~B}$ ), whereas in mutant receptors $C \Delta 72$ and $C \Delta 78$, the sensitivities to these two activators were substantially reduced. The $\mathrm{C} \Delta 104$ mutation displayed no sensitivity to capsaicin over the entire temperature range examined (Table 1). In this mutant, the average amplitude of the membrane current measured in the presence of capsaicin at $47^{\circ} \mathrm{C}$ was not different from that induced by heat in the control extracellular solution ( $n=11 ; p=0.18$; Student's paired $t$ test), suggesting the absence of any effective capsaicin-receptor interaction. Sequential deletions of 72, 78, and 104 residues from the $C$ terminal also reduced the membrane currents elicited by protons; however, responses to $\mathrm{pH} 5$ were still present in all of these mutants (Table 1).

\section{Interactions of heat, capsaicin, and protons in C-terminal truncated TRPV1}

We found that the capsaicin-elicited currents increased as the temperature was raised in both the wild type and in TRPV1 with truncated C tails (Fig. 2C). Similarly to DRG neurons (Vlachová et al., 2001), the smaller capsaicin responses at room temperature were potentiated considerably more by heat than were the large responses to capsaicin. In addition, there was an inverse correlation between the current amplitudes measured at room temperature and the ratios of the currents at $47^{\circ} \mathrm{C}$ to those at $25^{\circ} \mathrm{C}$. The degree of potentiation decreased with decreasing length of the C-terminal tail [Spearman correlation (number of cells measured): $r=-0.93$ (27), -0.94 (21), -0.74 (28), and -0.68 (21) for WT, $C \Delta 31, C \Delta 72$, and $C \Delta 78$, respectively].

Acidification of the extracellular bath solution (from 7.3 to 6.0) has two main effects on wild-type TRPV1 function. First, increased proton concentration markedly potentiates capsaicin and heat-induced responses. Second, at higher concentrations (less than $\mathrm{pH}$ 6.0) protons directly activate TRPV1 at room temperature. In our experiments, acidification of the extracellular solution from 7.3 to 6.0 facilitated the heat-induced responses in TRPV1-C $\Delta 31$, TRPV1-C $\Delta 42$, and TRPV1-C $\Delta 78$ mutants similarly to the way it did in the wild type (Fig. $2 D$ ). In the TRPV1$C \Delta 72$ and TRPV1-C $\Delta 104$ constructs, the extracellular application of $\mathrm{pH} 6$ did not produce a consistent increase in $I_{\mathrm{HEAT}}$. However, note that these results cannot be interpreted unequivocally, because it was difficult to exclude the possibility that some proton-induced sensitization was masked by receptor desensitization.

\section{Dose-response relationships for activation by capsaicin in C-terminally truncated TRPV1 mutants}

The heat- or capsaicin-induced responses in mutants $C \Delta 31$ and $\mathrm{C} \Delta 42$ displayed a slight, insignificant increase ( $p=0.1$ vs wildtype controls). This finding led us to compare the affinities for capsaicin in the C-terminally truncated mutants with that of the wild-type TRPV1. In the wild type, fits of dose-response relationships with the Hill equation (Fig. 3A,B) (see Materials and Methods) yielded values of $\mathrm{EC}_{50}=0.55 \pm 0.08$ at $30^{\circ} \mathrm{C}$ and $\mathrm{EC}_{50}=$ $0.24 \pm 0.02$ at $45^{\circ} \mathrm{C}(n=5 ; p<0.01$; paired $t$ test $)$, whereas the Hill coefficient appeared to be independent of temperature. From the dose-response relationships, it is evident that only the mutant $\mathrm{C} \Delta 31$ displayed differences in the apparent affinity for capsaicin at both 30 and $45^{\circ} \mathrm{C}$. Moreover, at $45^{\circ} \mathrm{C}$, the agonist efficacy of the mutant $\mathrm{C} \Delta 31$ was strongly increased (Fig. $3 D$ ). Actually, it is difficult to ascertain from the experimental protocol whether significant changes in dose-response relationships reflect increases in capsaicin potency and efficacy (i.e., agonistinduced current), or whether they occur because of changes in the activity mode of the channel (i.e., heat-induced current). Note that although the variability of the currents, the considerable tachyphylaxis, and the wide range of cooperativity (Fig. 2C) 


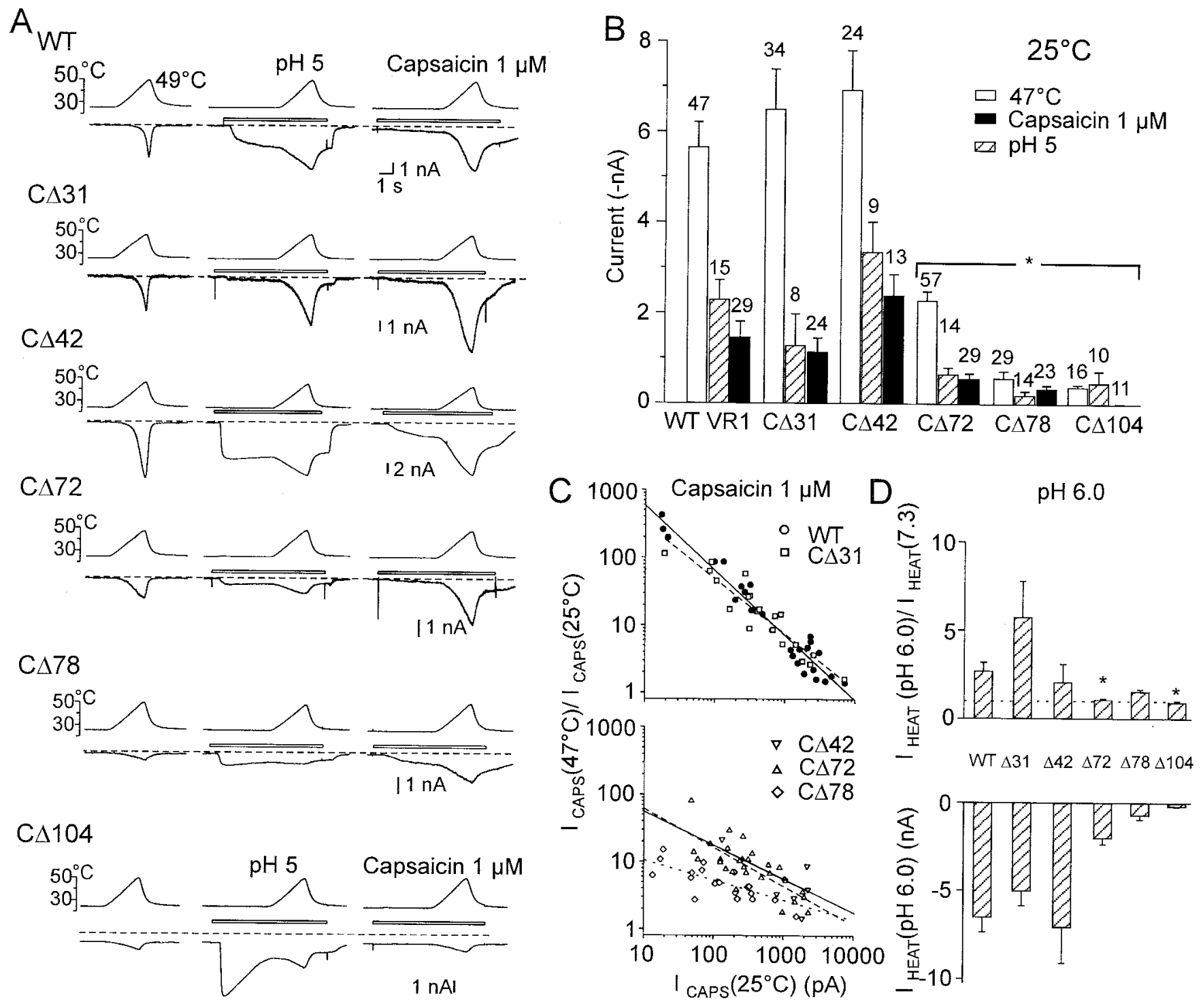

Figure 2. Whole-cell membrane currents induced by heat, protons, and capsaicin in wild-type TRPV1 and the C-terminal truncated mutants expressed in HEK293T cells. A, Heat-evoked currents $\left(I_{\text {HEAT }}\right)$ were induced by a 3 sec ramp of temperature increase to $49^{\circ} \mathrm{C}$ in standard extracellular solution (left), acidic pH (pH 5; middle), and capsaicin ( $1 \mu \mathrm{m}$; right). The cells clamped at $-70 \mathrm{mV}$ were superfused for the time indicated by the open bars shown above the records. Dashed lines indicate a zero membrane current. B, Quantitative analysis was performed by first stimulating cells by heat (from 25 to $49^{\circ} \mathrm{C}$ ) in the extracellular solution, followed by a $30 \mathrm{sec}$ washout, and then by stimulating them by heat in the presence of pH 5 or capsaicin. Mean \pm SEM responses evoked by heat, capsaicin, and low pH measured at room temperature, $25^{\circ} \mathrm{C}$, are shown $(p<0.05$; indicated with an asterisk). The numbers above each bar indicate the number of cells measured. $C$, Relative increase in capsaicin-induced peak currents at $47^{\circ} \mathrm{C}$ versus steady-state capsaicin current amplitudes measured at $25^{\circ} \mathrm{C}$ are plotted for individual cells transfected with wild-type and $C \Delta 31$ (top) and $C \Delta 42$, $C \Delta 72$, and $C \Delta 78$ (bottom). D, Analysis of proton-induced potentiation of heat-evoked currents. Mean ratios of peak currents induced by heat $\left(47^{\circ} \mathrm{C}\right)$ at $\mathrm{pH} 6$ to those measured at pH 7.3 are shown at the top. Average amplitudes of heat-induced currents recorded at pH 6 are shown at the bottom. Data represent means \pm SEM from 8 to 21 cells.

Table 1. Current responses of wild-type and C-terminal truncated mutants of TRPV1 channel to heat, capsaicin, and pH 5

\begin{tabular}{|c|c|c|c|c|c|c|}
\hline Channel & $I_{\text {HEAT }}$ at $47^{\circ} \mathrm{C}, \mathrm{nA}(n)$ & $\begin{array}{l}\text { Temperature } \\
\text { threshold, }{ }^{\circ} \mathrm{C}\end{array}$ & $I_{\text {CAPS }}$ at $25-47^{\circ} \mathrm{CnA}$ & $I_{\mathrm{pH} 5} \mathrm{nA}$ & $Q_{10}$ median (range) & $\begin{array}{l}\text { Temperature } \\
\text { range }\end{array}$ \\
\hline WT & $5.7 \pm 0.6(47)$ & $41.5 \pm 0.4(25)$ & $1.5 \pm 0.4(29)$ & $2.3 \pm 0.4(15)$ & $25.6(6.3-143)$ & $44-47^{\circ} \mathrm{C}(26)$ \\
\hline$c \Delta 31$ & $6.5 \pm 0.9(34)$ & $38.6 \pm 0.7(22)$ & $1.1 \pm 0.3(24)$ & $1.3 \pm 0.7(8)$ & $22.1(4.9-127)$ & $44-47^{\circ} \mathrm{C}(23)$ \\
\hline$C \Delta 42$ & $6.9 \pm 0.9(24)$ & $32.5 \pm 0.5(21)$ & $2.4 \pm 0.5(13)$ & $3.3 \pm 0.7(9)$ & $13.2(5.5-97)$ & $38-42^{\circ} \mathrm{C}(22)$ \\
\hline$C \Delta 72$ & $2.3 \pm 0.2(57)$ & $28.6 \pm 0.5(50)$ & $0.6 \pm 0.1(29)$ & $0.7 \pm 0.1(14)$ & $4.7(1.8-22)$ & $31-35^{\circ} \mathrm{C}(50)$ \\
\hline$C \Delta 78$ & $0.6 \pm 0.2(29)$ & & $0.3 \pm 0.1(23)$ & $0.2 \pm 0.1(14)$ & $1.7(1.3-7.5)$ & $27-32^{\circ} \mathrm{C}(25)$ \\
\hline$C \Delta 104$ & $0.4 \pm 0.1(16)$ & & $0(10)$ & $0.5 \pm 0.3(10)$ & $1.3(1.2-1.4)$ & $27-32^{\circ} \mathrm{C}(11)$ \\
\hline
\end{tabular}

complicate the interpretation, these data indicate that the distal region of the C-terminal domain could participate in the allosteric conformational changes producing opening after ligand binding.
C-terminal deletion mutants exhibit a lower temperature threshold for $I_{\text {HEAT }}$

The thermal sensitivity of TRPV1 mutants was examined using standard ramps of increasing temperature from 25 to $47^{\circ} \mathrm{C}$ 


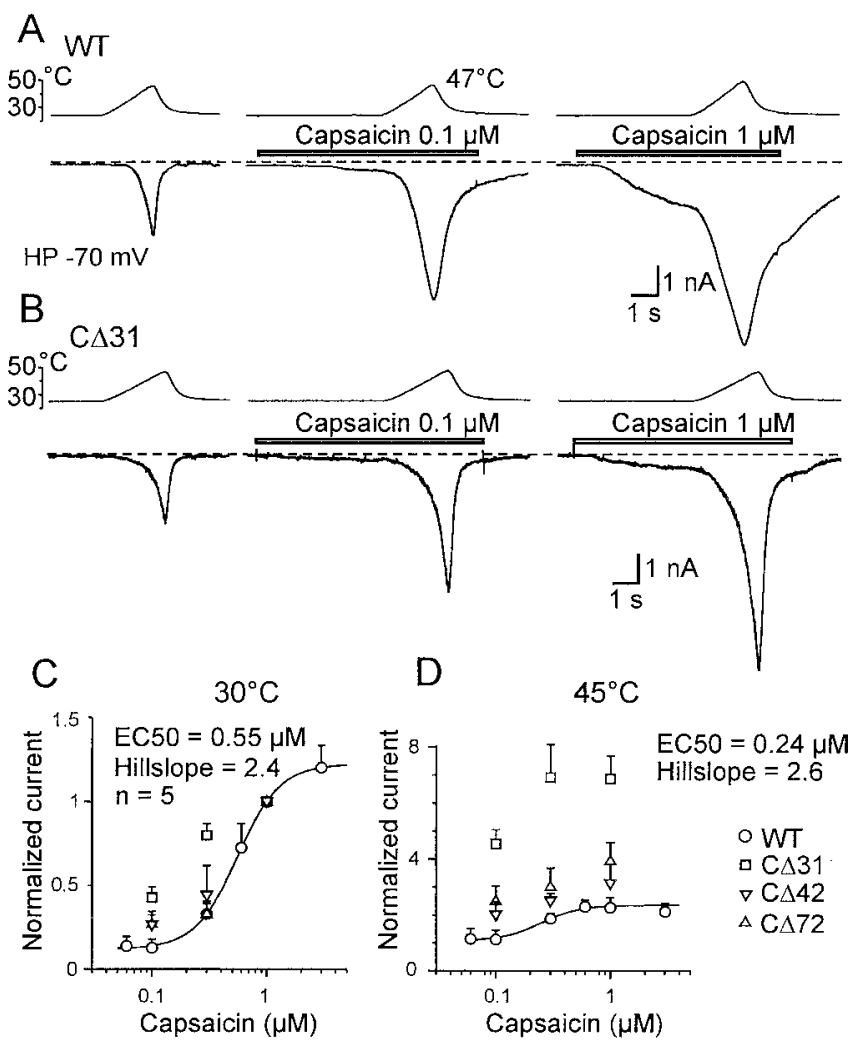

Figure 3. The effects of TRPV1 C-terminal truncation on receptor capsaicin efficacy and potency. $A$, Representative traces of whole-cell currents in WT TRPV1 activated by a heat ramp from 24 to $47^{\circ} \mathrm{C}$ in normal extracellular solution (left), $0.1 \mu \mathrm{m}$ capsaicin (middle), and $1 \mu \mathrm{M}$ capsaicin (right). The holding potential (HP) is $-70 \mathrm{mV}$. B, The HEK293T cell transiently transfected with mutant $C \Delta 31$ was exposed to heat ramps from 24 to $47^{\circ} \mathrm{C}$ in normal extracellular solution (left), $0.1 \mu \mathrm{m}$ capsaicin (middle), and $1 \mu \mathrm{m}$ capsaicin (right). The cells clamped at -70 $\mathrm{mV}$ were superfused for the time indicated by the open bars shown above the records. Dashed lines indicate a zero membrane current. $C$, The currents were normalized to the current produced by the application of $1 \mu \mathrm{m}$ capsaicin at $30^{\circ} \mathrm{C}$ and the mutants $C \Delta 31, C \Delta 42$, and $C \Delta 72$ were tested at agonist concentrations of $0.1,0.3$, and $1 \mu \mathrm{m}$. At $30^{\circ} \mathrm{C}$, capsaicin dose-response curves for wild-type receptor exhibited the average half-maximal concentration $0.55 \mu \mathrm{m}$ and Hill slope $2.4(n=5)$. The Hill equation was used for fitting control wild-type data (solid line). Before averaging across cells, data from each recording were normalized to the current induced by $1 \mu \mathrm{m}$ capsaicin measured at $30^{\circ} \mathrm{C}$. Data for each construct are shown as the means \pm SEM for four independent measurements. $D, A t 45^{\circ} \mathrm{C}$, capsaicin dose-response curves for wild-type receptor exhibited the average half-maximal concentration $0.24 \mu \mathrm{m}$ and Hill slope 2.6 $(n=5)$. Data from each recording were normalized to the current induced by $1 \mu \mathrm{m}$ capsaicin measured at $30^{\circ} \mathrm{C}$. C-terminal truncation had the most pronounced effects on both agonist efficacy and agonist potency in mutant $C \Delta 31$.

$\left(8.5^{\circ} \mathrm{C} / \mathrm{sec}\right)$. As expected, wild-type receptors responded vigorously to the heat stimulation within the noxious temperature range $\left(43-47^{\circ} \mathrm{C}\right)($ Fig. $4 \mathrm{~A})$. At a membrane potential of $-70 \mathrm{mV}$, the mean thermal threshold of the heat-induced membrane currents $\left(I_{\text {HEAT }}\right)$ was $41.5 \pm 0.4^{\circ} \mathrm{C}(n=25)$, which is in good agreement with the values measured by other authors (Caterina et al., 1997; Tominaga et al., 1998). In the wild-type TRPV1, the average peak amplitude of the noxious heat-induced response was $5.7 \pm$ $0.6 \mathrm{nA}$ at $47^{\circ} \mathrm{C}(n=47)$, and the median value of the temperature coefficient $\left(Q_{10}\right)$ was 25.6 (range, $6.3-143$ between 44 and $47^{\circ} \mathrm{C}$, $n=26$ ).

In the mutants $\mathrm{C} \Delta 31$ and $\mathrm{C} \Delta 42$, the magnitude of $I_{\mathrm{HEAT}}$ at $47^{\circ} \mathrm{C}$ was not significantly different from that of the wild-type TRPV1. In contrast, sequential deletions of 72, 78, and 104 residues from the $\mathrm{C}$-terminal end reduced the amplitudes of the heat-induced current markedly (Fig. 2 B). Sequential deletions of
31, 42, and 72 residues from the C-terminal end also shifted significantly the thermal threshold to $38.6 \pm 0.7^{\circ} \mathrm{C}(n=22)$, $32.5 \pm 0.5^{\circ} \mathrm{C}(n=21)$, and $28.6 \pm 0.5(n=50)$, respectively. Deletions of 78 and 104 residues from the C-terminal end shifted the thermal threshold toward temperatures close to that in the bath (Fig. $4 A, B$ ).

To determine the extent to which the C-terminal tail participates in the regulation of TRPV 1 channel activity induced by heat stimulation, the temperature coefficient $Q_{10}$ was estimated for each mutant in the respective temperature range, in which the Arrhenius plot was linear (correlation coefficient, $>0.99$ ) (Table 1). Interestingly, the distribution of $Q_{10}$ in the truncated mutant channel lacking the final 31 aa from the $\mathrm{C}$ terminal was similar to the wild type (Fig. $4 E$ ); however, the activation threshold was decreased significantly (Fig. $4 B, D$ ). This suggests that the distalmost C-tail region does not directly influence a high free-energy barrier between the resting and activated states of the TRPV1 channel; however, it shifts the thermal threshold for channel activation. The temperature coefficients were markedly reduced in all of the other mutants examined (Fig. 4F, Table 1). In both the wild-type and the truncated mutants, repeated applications of capsaicin or low $\mathrm{pH}$ were characterized by a substantial desensitization (tachyphylaxis); in contrast, in the case of repeated heat stimuli to $47^{\circ} \mathrm{C}$, the responses were reproducible for at least the first three exposures.

In contrast to the wild-type TRPV1, the mutants $\mathrm{C} \Delta 42, \mathrm{C} \Delta 72$, $\mathrm{C} \Delta 78$, and $\mathrm{C} \Delta 104$ frequently became saturated above $\sim 39^{\circ} \mathrm{C}$. The large resting membrane currents $\left(-521 \pm 76 \mathrm{pA}\right.$ at $25^{\circ} \mathrm{C}$; $n=16$ ) were observed at $-70 \mathrm{mV}$ in all cells expressing the $\mathrm{C} \Delta 104$ mutant channel from the start of the whole-cell recording. This was in contrast to the wild type and other constructs with less extensive deletions of the residues at the $\mathrm{C}$ end, which exhibited only negligible resting currents at $-70 \mathrm{mV}$. Because HEK293T cells were routinely maintained at $37^{\circ} \mathrm{C}$, the increased leak current might reflect a constitutive activation of mutant channels by the ambient temperature. However, two arguments suggest that it was unlikely that the decreased maximum responses reflected a low expression density: (1) We did not observe a reduced viability of the HEK239T cells expressing truncated mutants. (2) The maximum amplitudes induced by depolarizing voltage steps to +80 were lower by only $30 \%$ in the $\Delta 72$ mutant (which was still not significantly different from wild type), thus suggesting that the activation capacity of channels (or the number of functional channels on the cell membrane) was only slightly reduced. It was difficult to distinguish a specific heat response from the nonspecific effects of the temperature on the leakage current in the mutant $\mathrm{C} \Delta 104$, because $Q_{10}$ estimated over the entire temperature range was close to $\sim 1.5$. However, after leak subtraction, the amplitudes of the heat-induced currents in this construct were still significantly larger than maximum amplitudes recorded at $47^{\circ} \mathrm{C}$ in mock-transfected HEK293T cells held at $-70 \mathrm{mV}(-370 \pm 59 \mathrm{pA} ; n=13$ vs $-122 \pm 32 \mathrm{pA}$; $n=12$ ).

\section{Effects of the protein kinase $\mathrm{C}$ activator PMA on a mutant receptor $C \Delta 42$ that lacks a Ser residue at position 800}

It has been reported that the Ser residues S502 and S800 function as substrates for PKC-dependent phosphorylation of the TRPV1 receptor (Numazaki et al., 2002). To explore the role of the $\mathrm{C}$ terminal (S800) in the process of direct phosphorylation, we examined the effects of $1 \mu \mathrm{M}$ PMA, a specific membrane-permeable $\mathrm{PKC}$ activator, on the membrane currents evoked by heat in the wild-type TRPV1, the C $\Delta 31$ mutant, and the construct lacking 


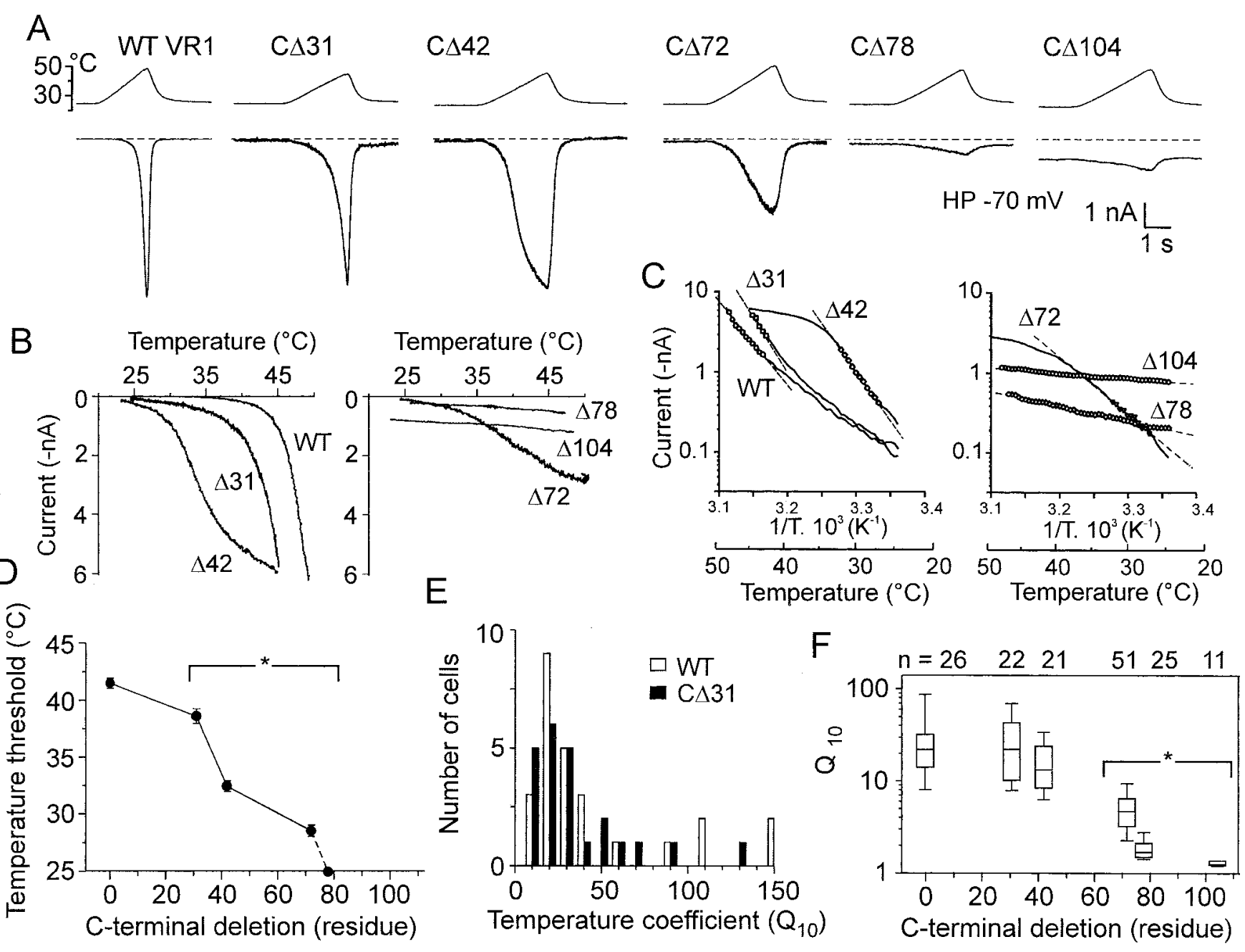

Figure 4. Sensitivity to heat in C-terminally truncated mutants. A, Representative heat-induced responses recorded from HEK293T cells transiently transfected with wild-type TRPV1, $C \Delta 31$, $C \Delta 42, C \Delta 72, C \Delta 78$, and $C \Delta 104$ mutants. Heat-evoked currents were induced by a 3 sec temperature ramp $\left(24-49^{\circ} C\right)$ in control extracellular solution. Dashed lines indicate a zero membrane current. $H P$, Holding potential. $B$, Temperature response profiles of the heat-induced currents shown in $A$. The threshold for $I_{\text {HeAT }}$ was $43.8,38.2$, and $28.9^{\circ} \mathrm{C}$ for wild-type, $C \Delta 31$, and $C \Delta 42$, respectively (left). In $C 104$ mutant, a pronounced resting membrane current was observed at room temperature (right). C, Arrhenius plot in which the current ( $y$-axis, log scale) was plotted against the reciprocal of the absolute temperature ( $x$-axis). The temperature coefficient, $Q_{10}$, was estimated for each mutant by linear regression from the slope of the Arrhenius plot in the temperature range indicated by respective symbols. $Q_{10}$ was $104.1,22.1,20.5,5.9,1.8$, and 1.2 for wild-type TRPV1, $C \Delta 31, C \Delta 42, C \Delta 72, C \Delta 78$, and $C \Delta 104$ mutants, respectively. $D$, Thermal threshold values plotted versus the number of residues deleted from the $C$-terminal tail of TRPV1 receptor. Sequential deletions of 31,42 , and 72 residues from the $C$-terminal end resulted in a significant shift of the thermal threshold to $38.6 \pm 0.7^{\circ} \mathrm{C}(\mathrm{SEM} ; n=22), 32.5 \pm 0.5^{\circ} \mathrm{C}(n=21)$, and $28.6 \pm 0.5(n=50)$, respectively. Deletions of 78 and 104 residues from the $\mathrm{C}$-terminal end caused a shift of the TRPV1 thermal threshold toward temperatures close to that in the bath. $E_{1} Q_{10}$ distribution in wild-type exhibits a median value of $25.6(n=26)$; the histogram shows that this distribution is similar to the distribution of $Q_{10}$ in the $C \Delta 31$ mutant (also see Table 1$)$. $F$, The median $Q_{10}$ plotted versus the number of residues deleted from the $C$-terminal tail of TRPV1 receptor. The ends of the boxes define the 25th and 75th percentiles, with a line at the median; error bars define the 10th and 90th percentiles. The asterisk indicates statistically significant difference from the wild type $(p<0.05)$.

the Ser residue at position $800, \mathrm{C} \Delta 42$ (Fig. $5 A-C)$. In the $\mathrm{C} \Delta 31$ mutant, PMA potentiated the heat-evoked currents by a factor of $\sim 1.5 \pm 0.2$ at $47^{\circ} \mathrm{C}(n=9)$. The potentiating effect was smaller, although still not significantly different from that of the wild-type TRPV1 ( $2.0 \pm 0.3 ; n=7)$. In contrast, PMA-mediated potentiation in the $\mathrm{C} \Delta 42$ mutant was significantly smaller $(1.2 \pm 0.1 ; n=$ 7) compared with the wild-type TRPV1. These findings support the study by Numazaki et al. (2002), indicating that Ser residue S800 participates in the PKC-dependent sensitization of heatevoked currents in TRPV1.

Voltage-dependent activation of the wild-type and C-terminal truncated TRPV1

At room temperature and at normal $\mathrm{pH} 7.3$, the rat cloned TRPV1 is activated by depolarizing voltages in the absence of any agonists (Reeve and Bevan, 2002; Vlachová et al., 2002). To determine the role of the $\mathrm{C}$ terminal in voltage-dependent TRPV1 activation, the current-voltage relationships of HEK293T cells transfected with either wild-type or C-terminal truncated TRPV1 were examined (Fig. 6A). In the wild-type TRPV1 $(n=36)$, depolarizing voltage steps elicited large outward membrane currents with a maximum amplitude of $1.8 \pm 0.1 \mathrm{nA}$ at $+80 \mathrm{mV}$. The interpolated reversal potential was $+6.1 \pm 0.7 \mathrm{mV}$, and the current-voltage relationships showed clear outward rectification. The mean RI (expressed as the ratio of current induced at +60 and $-40 \mathrm{mV}$; see Materials and Methods) was $9.2 \pm 1$. A region of negative slope conductance was recognized at potentials more negative than $-50 \mathrm{mV}$ in the cells with a very small resting current at a holding potential of more than $-80 \mathrm{pA}$ at $-70 \mathrm{mV}$. Untransfected or mock-transfected HEK293T cells exhibited 


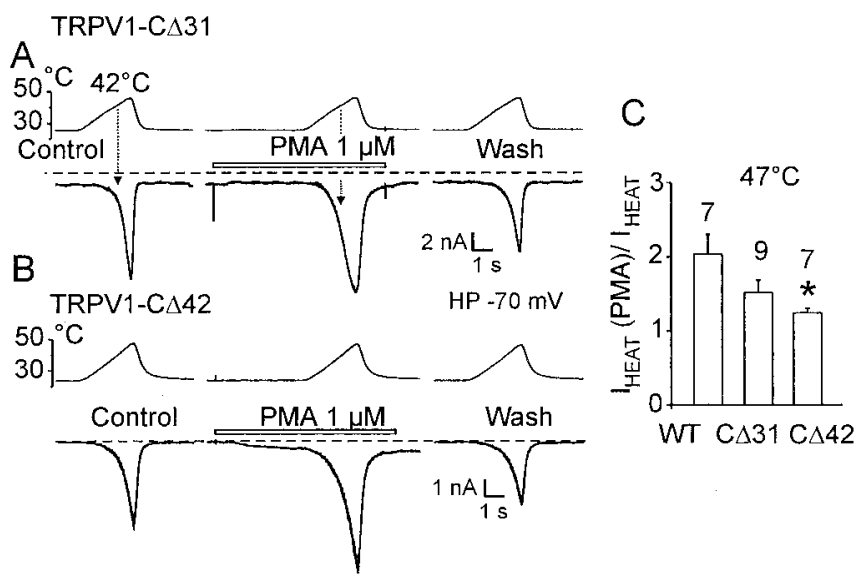

Figure 5. Effects of PMA on heat-evoked current in $C \Delta 31$ mutant and the construct lacking the Ser residue at position $800, C \Delta 42$. A, Heat-evoked currents were induced by ramps of increasing temperature from 25 to $47^{\circ} \mathrm{C}\left(8^{\circ} \mathrm{C} / \mathrm{sec}\right)$ in control extracellular solution (Control) and in the presence of $1 \mu \mathrm{m}$ PMA followed by a wash-off with control (Wash). The cells clamped at $-70 \mathrm{mV}$ were superfused for the time indicated by the open bars shown above the records. Dashed lines indicate a zero membrane current. B, Membrane currents recorded from TRPV1$C \triangle 42$-transfected HEK293T cells. C, PMA-induced potentiation of the heat-evoked currents at $47^{\circ} \mathrm{C}$ in $C \Delta 42$ compared with the wild-type and $C \Delta 31$ mutant ( $p<0.05$; indicated with an asterisk). Data represent means \pm SEM; the numbers above each bar indicate the number of cells measured.

only negligible voltage-induced currents, which were linearly related to membrane potential over $25-48^{\circ} \mathrm{C}$ (from -50 to +50 pA; $n=12$ ) (Fig. 6B).

The activation kinetics of wild-type TRPV1-mediated currents elicited by a depolarizing step from -80 to $+80 \mathrm{mV}$ was best described by the sum of two exponential functions in 31 of 36 cells $\left(\tau_{\text {slow }}=19.5 \pm 0.9 \mathrm{msec}, 70.0 \pm 2.1 \%\right.$; $\tau_{\text {fast }}=2.8 \pm 0.1 \mathrm{msec}$; $n=32$ ). In five cells, the activation process was best fitted by one exponential function $(9.0 \pm 1.1 \mathrm{msec} ; n=5)$. Repolarization to the holding membrane potential $(-70 \mathrm{mV})$ produced pronounced inward "tail currents." Detailed analysis of the TRPV1mediated deactivation kinetics revealed a fast $(2.2 \pm 0.1 \mathrm{msec})$ and a slow $(11.9 \pm 0.97 \mathrm{msec})$ time constant, with the relative contribution of $66.9 \pm 2.7 \%$ of the fast deactivating component.

A comparison of the outwardly rectifying currents induced by depolarizing voltage steps to $+80 \mathrm{mV}$ in the wild-type and in the C-terminal truncated TRPV1 constructs shows that there was a decrease in the outward current and a significant slowing of both the fast and the slow onset kinetic constants (Fig, 6A,C,E,F, Table 2 ) as the number of $\mathrm{C}$-terminal amino acid residues deleted was increased. Mutations TRPV1-C $\Delta 31$ and TRPV1-C $\Delta 42$ were less affected, whereas in mutants $C \Delta 72$ and $C \Delta 78$, the differences in voltage-activated currents were pronounced. The latter two mutants displayed an instantaneous component of the outward current at the onset and a significantly smaller tail current when normalized to the maximum outward current at $+80 \mathrm{mV}$ (Fig. $6 C, D)$. To quantify this observation, we analyzed the tail current amplitude in relation to the maximum current at $+80 \mathrm{mV}$. The amplitudes of the tail currents that were markedly lower in the $\mathrm{C} \Delta 72$ and $\mathrm{C} \Delta 78$ mutants were markedly reduced, suggesting that once activated, the mutant channels entered an inactive state more readily. These findings, together with the data showing that the mean time constants (and the proportions) of the tail currents were not significantly changed (Fig. 6E,F, Table 2), indicate that shortening of the TRPV1 C terminal decreased significantly the fraction of channels that retain their activity after repolarization.

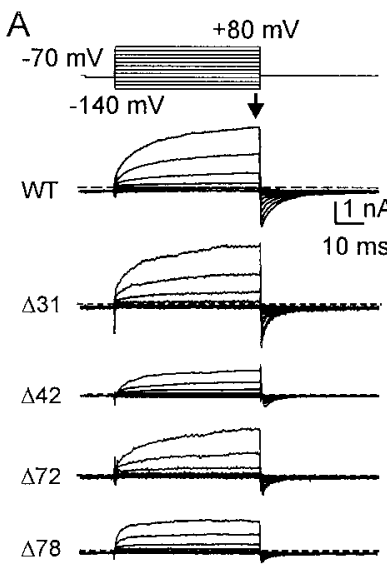

B
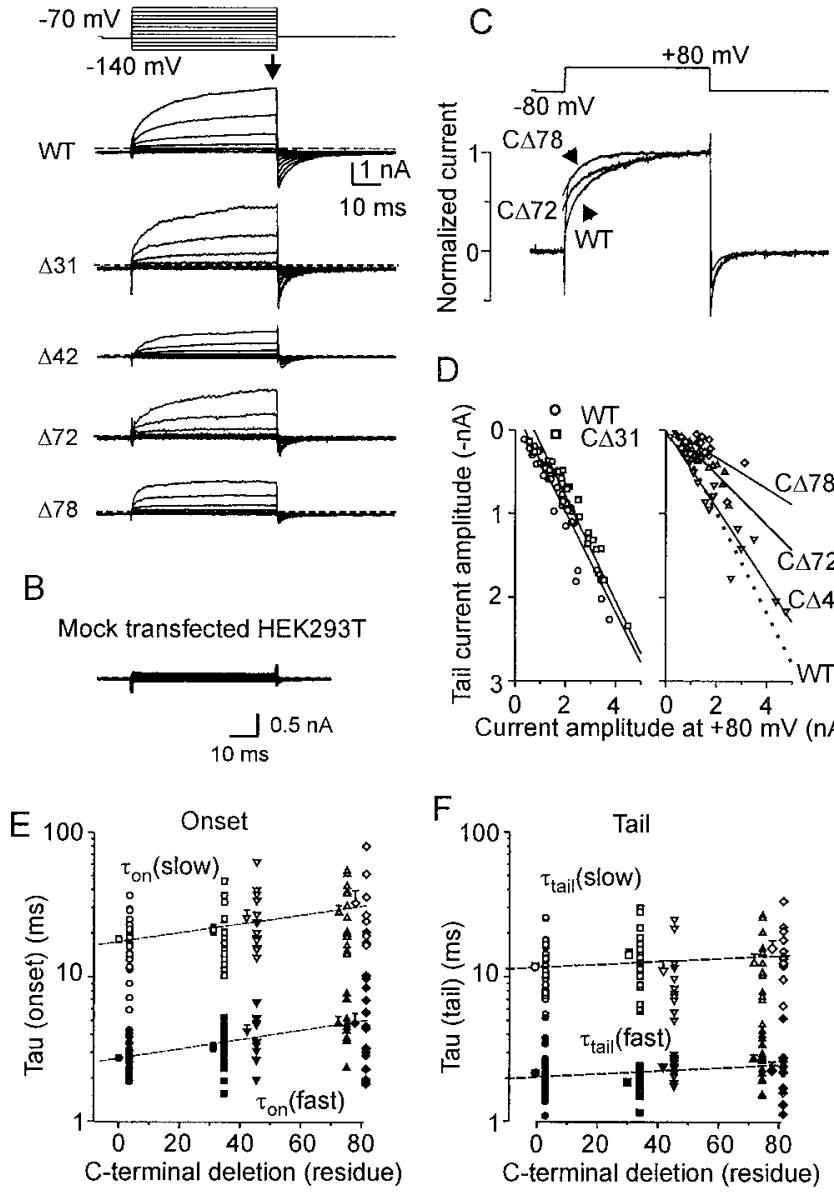

Figure 6. Voltage-activated currents in wild-type TRPV1 and C-terminal truncated mutants. $A$, Representative whole-cell membrane currents induced by a sequentially applied series of 50 msec voltage steps ranging from -140 to $+80 \mathrm{mV}$, in $+20 \mathrm{mV}$ increments. The currents were measured at the end of each pulse (arrow). $B$, The voltage protocol was completely ineffective in a mock-transfected HEK293T cell. C, Superimposed example responses induced by a depolarizing step from -80 to $+80 \mathrm{mV}$ in wild-type and the $C \Delta 72$ and $C \Delta 78$ mutants. $D$, The ratio between the outward current at $+80 \mathrm{mV}$ and the tail current amplitude in $C \Delta 31$ and $C \Delta 42$ is not statistically different from wild-type TRPV1 (Spearman correlation; $r=-0.98$ and -0.95 vs -0.96 for wild-type); on the contrary, it is markedly lower in $(\Delta 72$ and $(\Delta 78$ mutants $(-0.86$ and -0.68 , respectively). $E$, Kinetic analysis of the outward currents recorded from 36 , $24,12,17$, and 14 cells transfected with wild-type and $C \Delta 31, C \Delta 42, C \Delta 72$, and $C \Delta 78$ mutants, respectively. The onset currents induced by the depolarizing step from -80 to $+80 \mathrm{mV}$ were best fitted by the sum of two exponential functions with the slow component $\left[\tau_{\text {on }}\left(\right.\right.$ slow); open symbols], and the fast component $\left[\tau_{\text {on }}(\right.$ fast $)$; filled symbols]. Averages represent means \pm SEM. Linear regression analysis of the data yielded slopes of $0.0031(r=0.94)$ and 0.0033 ( $r=0.93$ ) for the slow and the fast components, respectively. $F$, The tail currents were best fitted by the sum of two exponential functions: $f(t)=A_{\text {fast }} \exp \left[-t / \tau_{\text {tail }}\right.$ (fast) $]+$ $A_{\text {slow }} \exp \left[-t / \tau_{\text {tail }}\right.$ (slow)]. The regression lines (dashed) were shallow, possessing slopes of $0.0011(r=0.27)$ and $0.0011(r=0.33)$ for the slow and the fast components, respectively.

A comparison of the current-voltage relationships of the mutants indicates that the current amplitudes at $+80 \mathrm{mV}$ were reduced with shortening of the TRPV1 C terminal (Fig. 6D), suggesting that the proximal regions of the C-terminal tail were required for efficient voltage gating of TRPV1. The mutant TRPV1-C $\Delta 104$ showed no sign of outward rectifying currents, and the leakage current (see above) was linearly related to membrane potential (data not shown).

To study the voltage-dependent gating of TRPV1 truncated mutants in more detail, the RIs of the $I-V$ relationships for mutant constructs were compared (Fig. 7A). The RI of the C $\Delta 31$ 
Table 2. Voltage-gated currents in wild-type and C-terminal truncated mutants of TRPV1 channel

\begin{tabular}{|c|c|c|c|c|c|c|}
\hline \multirow[b]{2}{*}{ Channel } & \multirow[b]{2}{*}{ Onset $\tau_{\text {slow }} \operatorname{msec}\left(A_{\text {slow }} \%\right)$} & \multirow[b]{2}{*}{$\tau_{\text {fast }} \operatorname{msec}(n)$} & \multicolumn{2}{|l|}{ Tail current } & \multirow{2}{*}{$\begin{array}{l}\text { Reversal potential, } \\
\mathrm{mV}(n)\end{array}$} & \multirow{2}{*}{$\begin{array}{l}\text { Rectification index } \\
{\left[I_{+60} /\left(60-V_{\text {rev }}\right)\right] /} \\
{\left[I_{-40} /\left(-40-V_{\text {rev }}\right)\right]}\end{array}$} \\
\hline & & & $\tau_{\text {slow }} \operatorname{msec}(n)$ & $\tau_{\text {fast }} \operatorname{msec}\left(A_{\text {fast }} \%\right)$ & & \\
\hline WT & $19.5 \pm 0.9(70 \pm 2)$ & $2.8 \pm 0.1(31)$ & $11.9 \pm 0.8(36)$ & $2.2 \pm 0.1(67 \pm 3)$ & $6.1 \pm 0.7(36)$ & $6.8 \pm 0.4$ \\
\hline$C \Delta 31$ & $21.0 \pm 1.9(69 \pm 3)$ & $3.3 \pm 0.3(16)$ & $15.1 \pm 1.5(22)$ & $1.9 \pm 0.1(74 \pm 3)$ & $5.2 \pm 0.7(24)$ & $11.6 \pm 1.6$ \\
\hline$C \Delta 42$ & $25.6 \pm 3.4(74 \pm 4)$ & $4.2 \pm 0.5(12)$ & $11.8 \pm 2.1(13)$ & $2.5 \pm 0.1(67 \pm 4)$ & $5.5 \pm 0.7(15)$ & $7.3 \pm 0.8$ \\
\hline$C \Delta 72$ & $27.9 \pm 3.3(38 \pm 5)$ & $4.8 \pm 0.6(11)$ & $13.3 \pm 2.2(14)$ & $2.8 \pm 0.2(64 \pm 6)$ & $4.7 \pm 1.3(17)$ & $4.8 \pm 0.6$ \\
\hline$C \Delta 78$ & $32.5 \pm 7.0(44 \pm 6)$ & $4.8 \pm 0.8(14)$ & $16.9 \pm 2.2(12)$ & $2.4 \pm 0.3(39 \pm 3)$ & $3.0 \pm 1.3(13)$ & $3.2 \pm 0.3$ \\
\hline
\end{tabular}
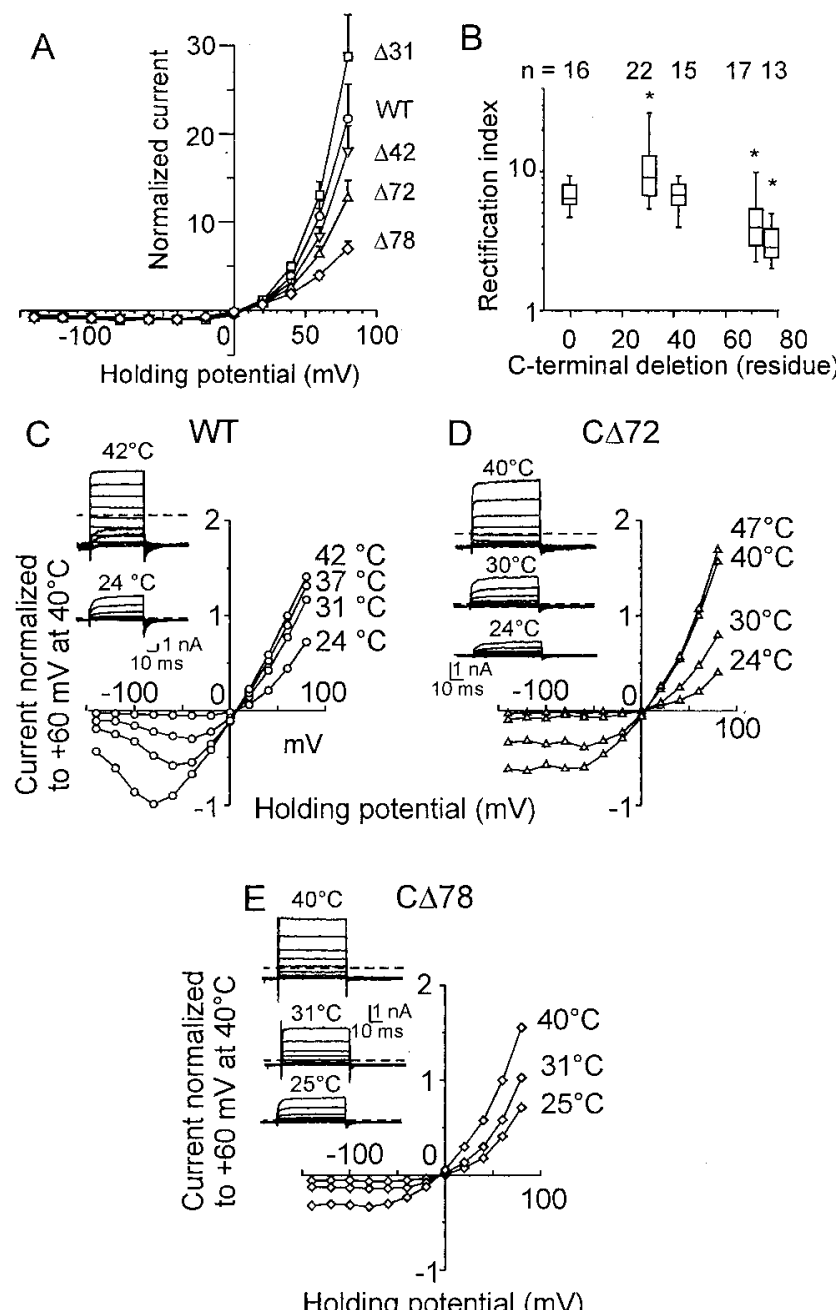

Figure 7. Outward currents in HEK293T cells transiently transfected with wild-type TRPV1 and $C$-terminal truncated mutants. $A$, Current-voltage relationship for wild-type and $C \Delta 31$, $C \Delta 42, C \Delta 72$, and $C \Delta 78$ mutants. Data were normalized to the value of the current at $-40 \mathrm{mV}$. $B$, For $C \Delta 31$, RI was significantly higher than that for wild-type, whereas significantly less RI was observed for $C \Delta 72$ and $C \Delta 78$ mutants (Table 2). The ends of the boxes define the 25 th and 75 th percentiles, with a line at the median; error bars define the 10 th and 90 th percentiles. The asterisks indicate significant differences from wild type $(p<0.05)$. C, The effect of temperature on the outward current rectification. Representative voltage-gated responses, recorded at $24^{\circ} \mathrm{C}$ (inset, bottom record) and at $42^{\circ} \mathrm{C}$ (inset, top record). Dashed lines indicate a zero membrane current in all records in this figure. Data were normalized to the value of the current measured at $+60 \mathrm{mV}$ and at $42^{\circ} \mathrm{C}$. D, Effect of temperature on outward current rectification properties in C $\Delta 72$ mutant. Representative recordings of voltage-evoked currents at 24,30 , and $40^{\circ} \mathrm{C}$ (inset). $E$, Note a considerable steady-state inward current induced at $31^{\circ} \mathrm{C}$, a temperature at which the mutant $C \Delta 78$ is thermally activated.

mutant was significantly higher than that of the wild-type receptor (Fig. 7B) (median 9.08 vs 6.42 in wild-type). In contrast, voltage-dependent rectification in the $\mathrm{C} \Delta 72$ and $\mathrm{C} \Delta 78$ mutants was significantly reduced (medians, 3.97 and 2.85).
Because the threshold of heat-evoked currents was close to room temperature in $\mathrm{C} \Delta 72$ and $\mathrm{C} \Delta 78$, we explored the effects of higher temperatures on the rectification properties of these constructs (Fig. 7C). In the wild-type channel, increasing the temperature from 24 to $42^{\circ} \mathrm{C}$ shifted the inflection point of the currentvoltage curve to more negative values (from approximately -40 to approximately $-80 \mathrm{mV}$ ) and decreased the RI from $5.4 \pm 0.5$ to $1.34 \pm 0.05(n=4)$ (Fig. $7 C)$. In contrast to the wild-type, the mean RI in $\mathrm{C} \Delta 78$ was not significantly affected by temperature $\left(3.31 \pm 0.47,2.37 \pm 0.14\right.$, and $2.50 \pm 0.21$ at 24,30 , and $40^{\circ} \mathrm{C}$, respectively; $n=4 ; p=0.10$ and $p=0.29$; Student's paired $t$ test). These data also confirm that the permeability of the TRPV1 channel is affected by the C-terminal tail.

Immunostaining of HEK293T cells transiently transfected with C-terminal truncated TRPV1 construct C $\Delta 155$

Truncation of the entire TRPV1 C-terminal domain was found to produce a nonfunctional channel. HEK293T cells expressing the C-terminal truncated mutant $\mathrm{C} \Delta 155$ did not respond to either capsaicin or heat (data not shown). Exposure of TRPV1-C $\Delta 155$ expressing cells to $\mathrm{pH} 5$ produced only transient currents, which inactivated within $\sim 2 \mathrm{sec}$, indicating the presence of acid-sensing ion channels expressed constitutively in HEK293 cells (Gunthorpe et al., 2001). To explore whether the fully truncated mutant can insert into the cell membrane, we used a polyclonal antibody against the first 21 aa residues of the rat TRPV1 N-terminal end and confocal laser scanning microscopy to compare the surface expression of wild type and the $\mathrm{C} \Delta 155$ mutant in transiently transfected HEK293T cells. Nonspecific binding of the primary antibody was determined by using nontransfected HEK293T cells. The nonspecific binding of the secondary antibody was determined in each experiment in the absence of primary antibody (data not shown). There were no significant differences between the distribution patterns of anti-TRPV1 immunoreactivity in the wild type and the $\mathrm{C} \Delta 155$ mutant (Fig. 8).
A

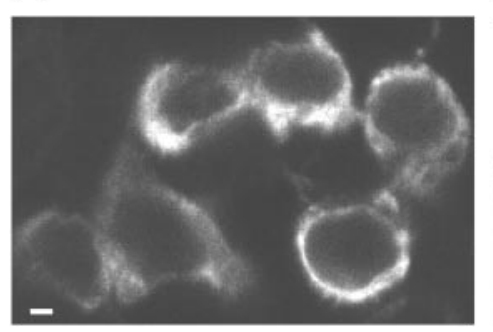

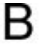

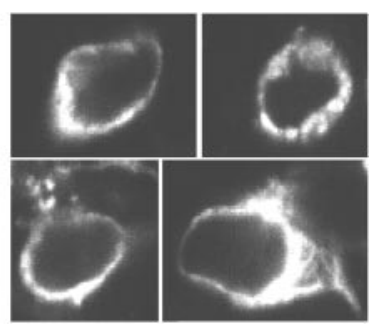

Figure 8. Surface expression of C-terminally truncated TRPV1 construct in transiently transfected HEK293T cells. A, Confocal microscope image of wild-type transfected HEK293T cells. Permeabilized cells were immunohistochemically labeled using a polyclonal antibody against the first 21 aa residues of the rat TRPV1 N-terminal end. Cells were labeled with FITC-conjugated donkey anti-rabbit lgG secondary antibody and visualized with standard FITC filters. B, Four HEK293T cells transiently transfected with truncated construct lacking the entire C-terminal end $C \Delta 155$. Scale bar, $5 \mu \mathrm{m}$. 
A

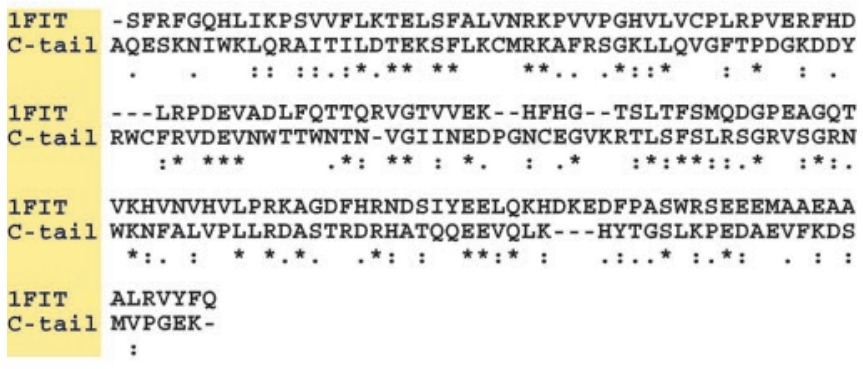

B
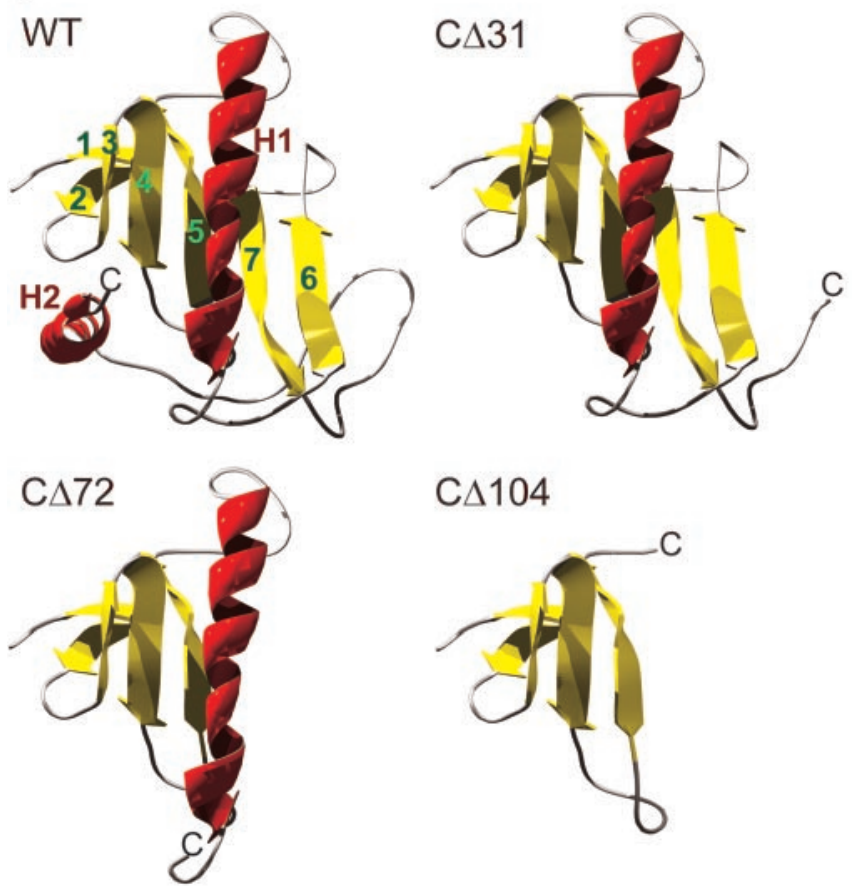

$\mathrm{C} \Delta 104$

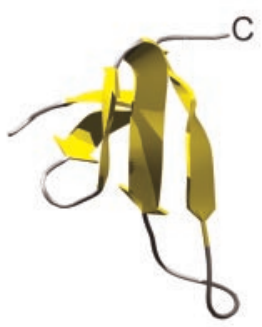

Figure 9. Molecular modeling of the TRPV1 C terminal. A, Sequence alignment of the cytoplasmic C terminal of TRPV1 from A690 to K838 and the template protein FHIT. Identical and similar amino acids of the stronger groups are indicated with an asterisk and colon, respectively. These amino acids should conserve the structure with a probability of $>95 \%$. Dots indicate similar amino acids of the lower groups that should conserve the structure with a lower probability. $B$, Predicted structure of the complete $C$ terminal of TRPV1 and the truncated mutants. $W T$, Ribbon diagram of the wild-type ( terminus (residues A690-K838). Homology modeling predicts two $\alpha$-helices $(H 1, H 2)$ and seven $\beta$-strands (1-7). Antiparallel strands 1 and 2 form a $\beta$-hairpin, and strands 3-7 form a five-stranded antiparallel sheet. $C \Delta 31$, This mutant (residues A690-T807) lacks the $\alpha$-helix H2. ( $\Delta 72$, In this construct (A690 - C766), secondary structural elements $\mathrm{H} 2$ and $\beta$-strands 6 and 7 are missing. $(\Delta 104$, The predicted structure of the truncated construct (A690-G734) consists only of $\beta$-strands $1-5$.

This assay indicated that the population of truncated construct $\mathrm{C} \Delta 155$ was processed and not retained in the intracellular compartments, and that the $\mathrm{C}$ terminal was not essential for trafficking the receptor to the HEK293T cell surface.

\section{Predicting the secondary and tertiary structures of the $\mathrm{C}$ terminal of TRPV 1}

To explain and predict the involvement of the C-terminal domain in TRPV1 channel function, the sequence of the TRPV1 C terminal from A690 to K838 was used for homology modeling. This section of the TRPV1 receptor shows a high sequence homology (44\%) to the FHIT protein, whose tertiary structure has been solved at $1.85 \AA$ resolution (Lima et al., 1997). The overall predicted structure of the TRPV1 C tail can be described as a general $\alpha+\beta$-type and can be further subclassed as an $\alpha+\beta$ meander fold. The $\mathrm{C}$ tail contains two helices, $\mathrm{H} 1$ and $\mathrm{H} 2$, and seven $\beta$-strands (Fig. 9B). Strands 3-7 form a five-stranded antiparallel sheet. The antiparallel strands 1 and 2 form a $\beta$-hairpin across from and at an angle to the other sheet. Helix $\mathrm{H} 1$ packs on one side of the five-stranded antiparallel $\beta$-sheet, and helix $\mathrm{H} 2$ packs on the same side and primarily interacts with strand 3 and the loop connecting strands 2 and 3. The template structure shows a disordered gap from residue 107 to residue 127 . Therefore, the structure of the large loop between $\beta$-strand 7 and the second helix was generated only from a loop database and is not based on homology. Probably this loop is highly flexible in reality; thus, the structure shown must be taken as only one speculative possibility for its conformation. The model of the $\mathrm{C}$ tail shows a high-quality stereochemistry, revealed by the Ramachandran plot calculated with Procheck (Laskowski et al., 1993). The values of the torsion angles of $88.6 \%$ of the residues were within the most favored regions, and $10.6 \%$ of the residue values were within additionally allowed regions of the Ramachandran plot. Only one residue was found to be in a generously allowed region; no residues were found in disallowed regions. The overall $g$-factor of the obtained structures showed a value of -0.16 , suggesting that the model presented here is of general validity. (Ideally, the value of the $g$-factor should be above -0.5 ; values below -1.0 may need investigation.) The three-dimensional representations of the C-terminal structure of truncated constructs $\mathrm{C} \Delta 31, \mathrm{C} \Delta 72$, and $C \Delta 104$ are demonstrated in the Figure $9 B$.

\section{Discussion}

Our results demonstrate that the intracellular C-terminal tail of the vanilloid receptor TRPV1 in HEK293T cells is required for functional channel activation. Sequential deletions of the residues from the $\mathrm{C}$ terminal decrease channel sensitivity to capsaicin, low $\mathrm{pH}$, and depolarizing voltage stimuli. However, the most striking effect of shortening the C terminal of TRPV1 was the altered sensitivity to heat. The threshold of heat-evoked currents was progressively shifted to lower temperatures with the decreasing length of the C-terminal tail. Deletions of 31 and 42 aa residues from the $\mathrm{C}$ terminal decreased the temperature threshold for channel activation by 3 and $9^{\circ} \mathrm{C}$, with little or no effect on capsaicin or proton responsiveness.

A general role for TRP channels in thermosensation has been supported by recent studies, which demonstrated that TRPV3 (Peier et al., 2002; Smith et al., 2002; Xu et al., 2002) and TRPV4 (Guler et al., 2002) are activated by warm temperatures. Our results indicate that the biophysical basis of thermosensation depends on the flexibility of the C-terminal peptide chain and the presence of residues that regulate the thermostability of the TRPV1 channel complex. The data provide evidence that the cytoplasmic C-terminal region is involved in conformational changes leading to channel activation. In the wild-type TRPV1 and the $C \Delta 31$ mutant, the strong temperature dependence $\left(Q_{10}=26\right.$ and 22$)$ suggests a very complex structural rearrangement during exposure to noxious heat; in contrast, the mild effects on gating in $\mathrm{C} \Delta 78$ and $\mathrm{C} \Delta 104$ truncation mutants $\left(Q_{10}, \sim 1.7\right)$ are compatible with a very simple conformational change.

TRPV1 is a nonselective cation channel that can be activated by a number of chemical agents of chemical or physical nature known to produce pain in humans (Caterina et al., 1997; Tominaga et al., 1998). TRPV1 most likely assembles into a homotet- 
rameric complex with a centrally located channel pore (Jahnel et al., 2001; Kedei et al., 2001). It is evident that there are several distinct domains on this receptor that can open the channel. The protein domains responsible for gating of the channel by protons can be modulated independently from the domain(s) involved in the gating by capsaicin or by heat (Welch et al., 2000). Two negatively charged glutamic acid residues, E600 and E648, located within the extracellular loop linking the transmembranespanning domain S5 with S6, appear to play a key role in sensing increased proton concentration (Jordt et al., 2000). The vanilloid binding site has been suggested to be located on the intracellular side of the membrane (Jung et al., 1999; Jordt and Julius, 2002).

Heterologously expressed TRPV1 can be activated by large depolarizing steps in the absence of exogenous agonists (Reeve and Bevan, 2002; Vlachová et al., 2002). This suggests that TRPV1 contains a transmembrane domain that senses membrane potential, and that positive potentials induce conformational changes of the protein leading to the channel opening. The existence of a domain sensing the depolarization of the membrane explains pronounced outward rectification of capsaicin-induced membrane currents that has been observed in native vanilloid receptor (Piper et al., 1999) and analyzed in great detail in the recombinant receptor (Gunthorpe et al., 2000). Our data demonstrate that the TRPV1 C terminal influences both permeation and gating (i.e., degree of rectification and deactivation kinetics). Therefore, it is possible that the functional effects of deleting the distal half of the $\mathrm{C}$ terminal suggest its close association with the putative voltage-sensing module, whose movement is coupled to the opening of the channel. An alternative explanation is that the conformational stability of the entire tetrameric protein complex may be altered in C-terminally truncated mutants, which display a significant decrease in voltage-gated outward currents.

The C-terminal region of TRPV1 participates in PKCdependent phosphorylation, probably at S800. In agreement with the study by Numazaki et al. (2002), sequential deletions showed that the heat-evoked currents in the construct lacking the Ser residue at position $800, \mathrm{C} \Delta 42$, are potentiated by a specific PKC activator, PMA, but to a lesser extent than $C \Delta 31$. This result suggests that the effects of PMA are likely to be influenced by the incomplete consensus site for PKC-dependent phosphorylation, and also that another region of TRPV1 has to be involved in PMA-induced sensitization.

Deletion of the entire TRPV1 C terminal was found to cause loss of channel sensitivity to all chemical, thermal, and voltage stimuli. Although the fully truncated mutant likely inserts into the cell membrane, as demonstrated by immunostaining with anti-N-terminal polyclonal antibody, it is not clear whether the mutant receptor is expressed as a functional channel in HEK293T cells. The TRPV1 5' splice variant is insensitive to noxious chemical stimuli (vanilloids, low $\mathrm{pH}$ ) and thermal stimuli (Schumacher et al., 2000b). Also, truncation of the entire TRPV1 C-terminal domain (155 residues) results in a loss of channel sensitivity to all chemical (capsaicin and $\mathrm{pH}$ ), thermal, and voltage stimuli. Therefore, the loss of TRPV1 sensitivity cannot be unambiguously interpreted as a loss of a specific site(s), because it could equally be caused by a large structural disturbance. Both the reduced sensitivity and the loss of function might be associated with impaired intrasubunit or intersubunit interactions among terminal domains during (or leading to) channel opening. For example, a close association between the N-terminal (tetramerization domain $\mathrm{T} 1$ ) and the $\mathrm{C}$ terminal has been described for the structurally related Shaker $\mathrm{K}^{+}$channel (Schulteis et al., 1996).
The cytoplasmic $\mathrm{C}$ terminal has been reported to be critical for expression and/or gating of various channels, including the $\alpha$ subunit of the human cardiac voltage-gated sodium channel SCN5A (Cormier et al., 2002), the two-pore domain mechanogated $\mathrm{K}^{+}$channel TREK-1 (Maingret et al., 2000), the bacterial Streptomyces lividans $\mathrm{K}^{+}$channel KcsA (Perozo et al., 1999), the voltage-gated $\mathrm{K}^{+}$channel human ether-à-go-go-related gene cardiac $\mathrm{K}^{+}$channel (Aydar and Palmer, 2001), the Kv2.1 potassium channel with delayed rectifier properties (Bentley et al., 1999), the Drosophila Shaker $\mathrm{K}^{+}$channel (Schulteis et al., 1996), and the small conductance $\mathrm{Ca}^{2+}$-activated $\mathrm{K}^{+}$channel (Bruening-Wright et al., 2002). It is also important for the cyclic nucleotide-gated channel, in which direct binding of cyclic nucleotides in the C-terminal region is transduced to open a gate that presumably resides in the channel selectivity filter (Flynn and Zagotta, 2001). Importantly, these latter five tetrameric channels belong to a superfamily of structurally related six-transmembrane domain proteins that also includes the TRP channel family; this suggests the possible existence of physical and structural analogies between the gating mechanisms.

In the molecular model based on homology with the fragile histidine triad protein presented here, the distalmost 31 aa residues of the TRPV1 C terminal (Q808-K838) correspond to the $\alpha$-helical structure $\mathrm{H} 2$ and the large flexible loop connecting it with $\beta$-sheet 7 (Fig. 9B). Removal of this region is sufficient to shift the thermal threshold for activation from 42 to $39^{\circ} \mathrm{C}$. This structural part seems also to modulate the sensitivity to capsaicin as the mutant $C \Delta 31$ exhibits increased agonist efficacy (Fig. 3). Deletion of the remaining short part of the connecting loop (R797-K838) markedly decreased the thermal threshold (to $33^{\circ} \mathrm{C}$ ) for receptor activation. The large loop seems to be anchored between helix $\mathrm{H} 2$ and $\beta$-strand 7 to form itself a highly flexible structure that regulates steric accessibility to the core $\beta$-sheet. The effects of the deletion of the remaining 11 loop amino acids in the mutant $\mathrm{C} \Delta 42$ suggest the importance of $\beta$-sheets 6 and 7 in channel activation. This view is also supported by construct $\mathrm{C} \Delta 72$, which lacks $\beta$-strands 6 and 7 (E767-K838) and displays profound changes in channel function. The thermal threshold dropped from 41.5 to $28.6^{\circ} \mathrm{C}, Q_{10}$ decreased from 25.6 to 4.7 , and the currents induced by capsaicin, $\mathrm{pH} 5$, heat, and voltage decreased significantly, suggesting a distinct role of these two $\beta$-strands in the $\mathrm{C}$ terminal of TRPV1. In the model of the mutant $\mathrm{C} \Delta 104$, the helix $\mathrm{H} 1$ is lost. This helix is a relatively long helical structure (18 residues) on the surface of the protein. Accessibility for multimerization in its entire length and its distribution of hydrophobic residues makes it a good candidate for taking part in a multimerization module. This could either be a coiled coil controlling the tetrameric organization of the channel or an interaction with another receptor region (e.g., of the $\mathrm{N}$ terminal). The $\beta$-hairpin formed by the first two antiparallel strands does not seem to exhibit any functional role; however, it could stabilize the proper position of the $\mathrm{C}$ tail toward the membrane.

In conclusion, our results provide evidence that the structural basis of the thermal sensitivity of the TRPV1 channel resides in the distal half of the $\mathrm{C}$ terminal, and that this terminal region contributes to the regulation of chemically induced, thermally induced, and voltage-induced activity of the TRPV1 channel.

\section{References}

Aydar E, Palmer C (2001) Functional characterization of the C-terminus of the human ether-a-go-go-related gene $\mathrm{K}^{+}$channel (HERG). J Physiol (Lond) 534:1-14. 
Bentley GN, Brooks MA, O’Neill CA, Findlay JB (1999) Determinants of potassium channel assembly localised within the cytoplasmic C-terminal domain of Kv2.1. Biochim Biophys Acta 1418:176-184.

Bruening-Wright A, Schumacher MA, Adelman JP, Maylie J (2002) Localization of the activation gate for small conductance $\mathrm{Ca}^{2+}$-activated $\mathrm{K}^{+}$ channels. J Neurosci 22:6499-6506.

Caterina MJ, Schumacher MA, Tominaga M, Rosen TA, Levine JD, Julius D (1997) The capsaicin receptor: a heat-activated ion channel in the pain pathway. Nature 389:816-824.

Caterina MJ, Rosen TA, Tominaga M, Brake AJ, Julius D (1999) A capsaicin-receptor homologue with a high threshold for noxious heat. Nature 398:436-441.

Caterina MJ, Leffler A, Malmberg AB, Martin WJ, Trafton J, Petersen-Zeitz KR, Koltzenburg M, Basbaum AI, Julius D (2000) Impaired nociception and pain sensation in mice lacking the capsaicin receptor. Science 288:306-313.

Chuang HH, Prescott ED, Kong H, Shields S, Jordt SE, Basbaum AI, Chao MV, Julius D (2001) Bradykinin and nerve growth factor release the capsaicin receptor from PtdIns(4,5)P2-mediated inhibition. Nature 411:957-962.

Clapham DE, Runnels LW, Strubing C (2001) The TRP ion channel family. Nat Rev Neurosci 2:387-396.

Cormier JW, Rivolta I, Tateyama M, Yang AS, Kass RS (2002) Secondary structure of the human cardiac $\mathrm{Na}^{+}$channel C terminus: evidence for a role of helical structures in modulation of channel inactivation. J Biol Chem 277:9233-9241.

Davis JB, Gray J, Gunthorpe MJ, Hatcher JP, Davey PT, Overend P, Harries MH, Latcham J, Clapham C, Atkinson K, Hughes SA, Rance K, Grau E, Harper AJ, Pugh PL, Rogers DC, Bingham S, Randall A, Sheardown SA (2000) Vanilloid receptor-1 is essential for inflammatory thermal hyperalgesia. Nature 405:183-187.

Dittert I, Vlachová V, Knotková H, Vitásková Z, Vyklický L, Kress M, Reeh PW (1998) A technique for fast application of heated solutions of different composition to cultured neurones. J Neurosci Methods 82:195-201.

Flynn GE, Zagotta WN (2001) Conformational changes in S6 coupled to the opening of cyclic nucleotide-gated channels. Neuron 30:689-698.

Guler AD, Lee H, Iida T, Shimizu I, Tominaga M, Caterina M (2002) Heatevoked activation of the ion channel, TRPV4. J Neurosci 22:6408-6414.

Gunthorpe MJ, Harries MH, Prinjha RK, Davis JB, Randall A (2000) Voltage- and time-dependent properties of the recombinant rat vanilloid receptor (rVR1). J Physiol (Lond) 525:747-759.

Gunthorpe MJ, Smith GD, Davis JB, Randall AD (2001) Characterisation of a human acid-sensing ion channel (hASIC1a) endogenously expressed in HEK293 cells. Pflügers Arch 442:668-674.

Gunthorpe MJ, Benham CD, Randall A, Davis JB (2002) The diversity in the vanilloid (TRPV) receptor family of ion channels. Trends Pharmacol Sci 23:183-191.

Jahnel R, Dreger M, Gillen C, Bender O, Kurreck J, Hucho F (2001) Biochemical characterization of the vanilloid receptor 1 expressed in a dorsal root ganglia derived cell line. Eur J Biochem 268:5489-5496.

Jordt SE, Julius D (2002) Molecular basis for species-specific sensitivity to "hot" chili peppers. Cell 108:421-430.

Jordt SE, Tominaga M, Julius D (2000) Acid potentiation of the capsaicin receptor determined by a key extracellular site. Proc Natl Acad Sci USA 97:8134-8139.

Jung J, Hwang SW, Kwak J, Lee SY, Kang CJ, Kim WB, Kim D, Oh U (1999) Capsaicin binds to the intracellular domain of the capsaicin-activated ion channel. J Neurosci 19:529-538.

Kedei N, Szabo T, Lile JD, Treanor JJ, Olah Z, Iadarola MJ, Blumberg PM (2001) Analysis of the native quaternary structure of vanilloid receptor 1 . J Biol Chem 276:28613-28619.

Kwak J, Wang MH, Hwang SW, Kim TY, Lee SY, Oh U (2000) Intracellular ATP increases capsaicin-activated channel activity by interacting with nucleotide-binding domains. J Neurosci 20:8298-8304.

Laskowski RA, MacArthur MW, Moss DS, Thornton JM (1993) PROCHECK: a program to check the stereochemical quality of protein structures. J Appl Crystallogr 26:283-291.

Liedtke W, Choe Y, Marti-Renom MA, Bell AM, Denis CS, Sali A, Hudspeth
AJ, Friedman JM, Heller S (2000) Vanilloid receptor-related osmotically activated channel (VR-OAC), a candidate vertebrate osmoreceptor. Cell 103:525-535.

Lima CD, D’Amico KL, Naday I, Rosenbaum G, Westbrook EM, Hendrickson WA (1997) MAD analysis of FHIT, a putative human tumor suppressor from the HIT protein family. Structure 5:763-774.

Maingret F, Lauritzen I, Patel AJ, Heurteaux C, Reyes R, Lesage F, Lazdunski M, Honore E (2000) TREK-1 is a heat-activated background $\mathrm{K}^{+}$channel. EMBO J 19:2483-2491.

Numazaki M, Tominaga T, Toyooka H, Tominaga M (2002) Direct phosphorylation of capsaicin receptor VR1 by protein kinase C $\epsilon$ and identification of two target serine residues. J Biol Chem 277:13375-13378.

Peier AM, Reeve AJ, Andersson DA, Moqrich A, Earley TJ, Hergarden AC, Story GM, Colley S, Hogenesch JB, McIntyre P, Bevan S, Patapoutian A (2002) A heat-sensitive TRP channel expressed in keratinocytes. Science 296:2046-2049.

Perozo E, Cortes DM, Cuello LG (1999) Structural rearrangements underlying $\mathrm{K}^{+}$-channel activation gating. Science 285:73-78.

Piper AS, Yeats JC, Bevan S, Docherty RJ (1999) A study of the voltage dependence of capsaicin-activated membrane currents in rat sensory neurones before and after acute desensitization. J Physiol (Lond) 518:721-733.

Reeve AJ, Bevan S (2002) Voltage-dependent activation of rat cloned vanilloid receptor (VR1) in the absence of exogenous agonists. Paper presented at 10th World Congress on Pain, San Diego, CA, August.

Sali A, Blundell TL (1993) Comparative protein modelling by satisfaction of spatial restraints. J Mol Biol 234:779-815.

Schulteis CT, Nagaya N, Papazian DM (1996) Intersubunit interaction between amino- and carboxyl-terminal cysteine residues in tetrameric shaker $\mathrm{K}^{+}$channels. Biochemistry 35:12133-12140.

Schumacher MA, Jong BE, Frey SL, Sudanagunta SP, Capra NF, Levine JD (2000a) The stretch-inactivated channel, a vanilloid receptor variant, is expressed in small-diameter sensory neurons in the rat. Neurosci Lett 287:215-218

Schumacher MA, Moff I, Sudanagunta SP, Levine JD (2000b) Molecular cloning of an $\mathrm{N}$-terminal splice variant of the capsaicin receptor: loss of $\mathrm{N}$-terminal domain suggests functional divergence among capsaicin receptor subtypes. J Biol Chem 275:2756-2762.

Smith GD, Gunthorpe MJ, Kelsell RE, Hayes PD, Reilly P, Facer P, Wright JE, Jerman JC, Walhin JP, Ooi L, Egerton J, Charles KJ, Smart D, Randall AD, Anand P, Davis JB (2002) TRPV3 is a temperature-sensitive vanilloid receptor-like protein. Nature 418:186-190.

Thompson JD, Gibson TJ, Plewniak F, Jeanmougin F, Higgins DG (1997) The CLUSTAL $\mathrm{X}$ windows interface: flexible strategies for multiple sequence alignment aided by quality analysis tools. Nucleic Acids Res 25:4876-4882.

Tominaga M, Caterina MJ, Malmberg AB, Rosen TA, Gilbert H, Skinner K, Raumann BE, Basbaum AI, Julius D (1998) The cloned capsaicin receptor integrates multiple pain-producing stimuli. Neuron 21:531-543.

Vlachová V, Lyfenko A, Orkand RK, Vyklický L (2001) The effects of capsaicin and acidity on currents generated by noxious heat in cultured neonatal rat DRG neurones. J Physiol (Lond) 533.3:717-728.

Vlachová V, Susankova K, Lyfenko A, Kuffler DP, Vyklicky L (2002) Kapsaicinový receptor: specifický iontový kanál pro detekci bolestivých podnětů. Psychiatrie 6:6-13.

Vyklický L, Vlachová V, Vitásková Z, Dittert I, Kabát M, Orkand RK (1999) Temperature coefficient of membrane currents induced by noxious heat in sensory neurones in the rat. J Physiol (Lond) 517:181-192.

Welch JM, Simon SA, Reinhart PH (2000) The activation mechanism of rat vanilloid receptor 1 by capsaicin involves the pore domain and differs from the activation by either acid or heat. Proc Natl Acad Sci USA 97:13889-13894.

Xu H, Ramsey IS, Kotecha SA, Moran MM, Chong JA, Lawson D, Ge P, Lilly J, Silos-Santiago I, Xie Y, DiStefano PS, Curtis R, Clapham DE (2002) TRPV3 is a calcium-permeable temperature-sensitive cation channel. Nature 418:181-186.

Xue Q, Yu Y, Trilk SL, Jong BE, Schumacher MA (2001) The genomic organization of the gene encoding the vanilloid receptor: evidence for multiple splice variants. Genomics 76:14-20. 